\title{
Zoning of the territory with snow removal using snow melting plants
}

\author{
Anastasia Ivanova ${ }^{1, *}$, Sergey Pavlov ${ }^{1}$, Luka Akimov ${ }^{2}$, and Lidya Zakharova ${ }^{3}$ \\ ${ }^{1}$ Peter the Great St.Petersburg Polytechnic University, Polytechnicheskaya, 29, St. Petersburg, \\ 195251, Russia \\ ${ }^{2}$ Politecnoco di Milano, 32 Piazza Leonardo da Vinci, Milano, 20133, Italian Republic \\ ${ }^{3}$ Moscow State University of Civil Engineering, 26 Yaroslavskoye Shosse, 26, Moscow, 129337, \\ Russia
}

\begin{abstract}
In this paper, the issue of clearing the territory of snow with the use of snow melting units is being considered. The operating principle of the snow-melting stations is based on sewage heat) melting the snow collected in the snow collection chambers. Snow melt water mixed with wastewater is discharged into the collectors and transported to have a full treatment cycle at the wastewater treatment plant. Three problems of urban snow-melting process are considered. The solution of three problems is proposed: compiling a list of signs of mandatory snow removal zones; the allocation of the main zones corresponding to the proposed features; method of determining the amount of snow that is mandatory for export from the territory of the zone.
\end{abstract}

\section{Introduction}

Snow, which is collected from streets, squares and roads, until recently was discharged into the nearest ponds without treatment, since it was not attributed to the waste of the settlement, as is done in most parts of the world [1], but to conventionally pure natural precipitation. Currently, with the ever increasing number of cars and industrial emissions, snow, as it falls out and temporarily stored on the ground, adsorbs from the air and accumulates from road surfaces oil products, heavy metals, household waste, anti-ice materials, etc. (up to 60 pollutants). The discharge of the snow mass without cleaning and disinfection in the dump entails contamination of the soil, surface and underground water sources, and ultimately and deterioration of human health, the state of flora and fauna.

Snow belongs to the category of waste of the 4th class of danger [2], therefore the solution of the problems associated with its disposal is a serious link in the chain of measures to clean up city streets.

In large cities, more recently, the processing of snow is quite harmless and does not aggravate the work of treatment plants [3]. The essence of this process is the use of special

\footnotetext{
* Corresponding author: coolhabit@yandex.ru
} 
complexes that are designed to collect, transport, melting snow, partial purification of thawed water and removing it through the municipal sewerage system to urban treatment facilities.

Basically, the principles of snow removal in all countries are the same. According to the regulations snow should be removed during the first hours of snowfall, not allowing its condensation, first of all, from central streets and streets with the highest capacity [4,5]. In many countries, city-to-zone systems are used to optimize the snow removal process [58]. Control systems determine the correspondence of city districts and snow melting installations. The scheme can be adjusted depending on the load of a particular snow melting point, and also depending on the situation on the roads (Fig.1). Such an automated method of distributing snow has not yet found wide application, but it will soon become common for large megacities, and not just for small European cities [9-11].

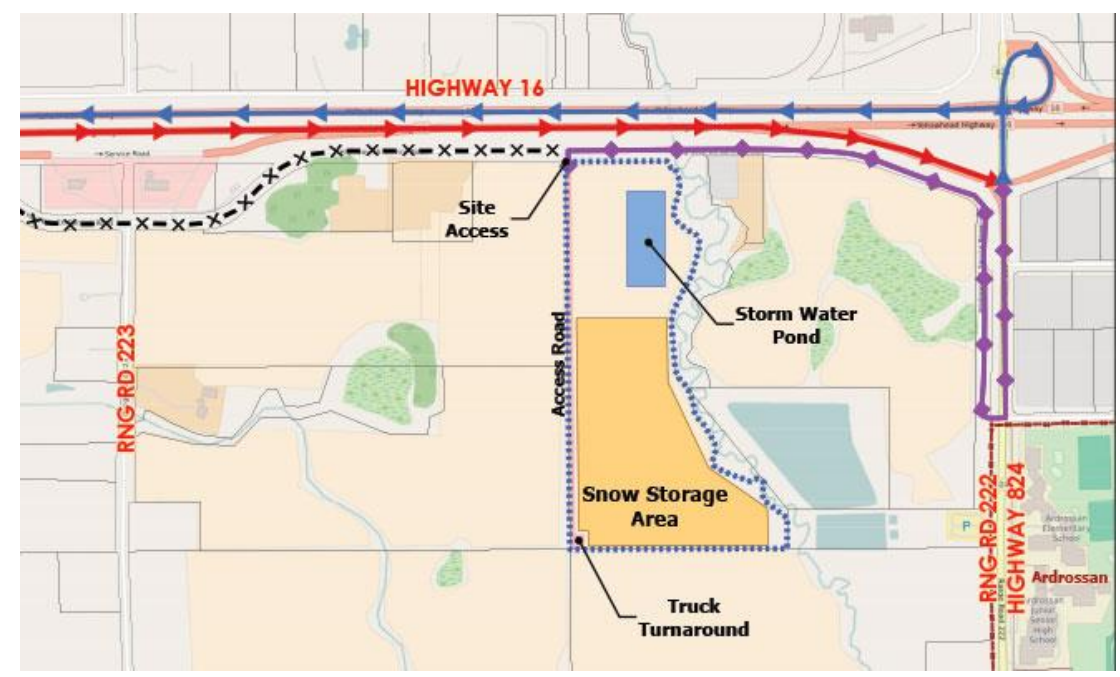

Fig.1. Snow-melting facilities map example.

But despite the fact that it is proposed to divide the territory of the city into zones, none of the sources mention the division of the city into zones depending on the type of development, which, in the opinion of the authors, is very important [8, 11-13].

The purpose of this work is to propose the division of the settlement into zones of mandatory export of snow when using stationary snow melting units.

In this paper, preliminary solutions are proposed for the following tasks that contribute to the achievement of the formulated goal:

1. Drawing up a list of signs of mandatory snow removal zones;

2. Identification of the main zones corresponding to the proposed features;

3. Methods for calculating the amount of snow removed from the zone.

\section{Materials and methods}

In this paper, the zoning method of the territory is used, taking into account the location of stationary snow-melting installations in the city. Data on the topography of settlements and their climatic characteristics are used as a source material [13-17].

In order to solve the first of the above tasks, the following list of characteristics is proposed, which makes it possible to characterize the zone of mandatory export of snow, and the characteristics of these parameters. The characteristics and their characteristics are summarized in Table 1. 
Table 1. The features and characteristics of the areas that define the area of export of snow.

\begin{tabular}{|l|l|}
\hline Features & Characteristics \\
\hline Density of building $\left(^{*}\right)$ & $\begin{array}{l}\text { Dense / free / characteristic for industrial } \\
\text { zone }\end{array}$ \\
\hline Type of building & Residential / non-residential, old / new \\
\hline Possibility of location of stationary snow melting units & Possible / impossible \\
\hline The proximity of the location of landfills for storing snow $(* *)$ & $\begin{array}{l}\text { In an economically advantageous } \\
\text { delivery zone / outside the economically } \\
\text { advantageous delivery area }\end{array}$ \\
\hline Presence of stationary snow melting units on the territory & Available / Not available \\
\hline $\begin{array}{l}\text { The presence of sewer collectors, able to take melted water from } \\
\text { a snow melting unit (consumption of about 200 l/s) }\end{array}$ & Available / Not available \\
\hline Availability of free sites for snow melting points & Available / Not available \\
\hline $\begin{array}{l}\text { The proximity of residential buildings to a snow melting } \\
\text { installation }\end{array}$ & $\begin{array}{l}\text { Safe in terms of noise / dangerous noise } \\
\text { level }\end{array}$ \\
\hline Availability of suitable highways for export of snow & Available / Not available \\
\hline $\begin{array}{l}\text { The presence of sewage pumping stations (SPS) (if necessary } \\
\text { pumping meltwater from a snow melting plant from the } \\
\text { underlying reservoir to the overlying one) }\end{array}$ & Available / Not available \\
\hline
\end{tabular}

In paragraph $(*)$, under «dense» construction is meant residential and public buildings with multi-storey buildings; under the «free» building - the territory of fashionable suburbs with cottages. Paragraph $(* *)$ refers to cities where storage and processing of snow on landfills are allowed. The above list of features is preliminary (may be supplemented), but, in the opinion of the authors, it sufficiently fully characterizes the territory considered in terms of the export of snow and its utilization.

To identify the main fundamentally different zones of compulsory export of snow, the authors have the following reasons:

1. Stationary snow-melting plants (Fig.2) can not be located in the area of a dense residential complex (there is no place for accommodation because of the high density of construction, high noise level, it is impossible to move a large number of heavy vehicles that bring snow to a fixed installation for snowmelt).

2. In a suburban area, stationary snow-melting plants are inefficient, since they are located in a zone economically unprofitable for transportation, there are no collectors of the water disposal system.

3. The most realistic zone for stationary snow melting plants is the industrial zone of the city for the following reasons: the presence of wide driveways, sewage collectors are often designed to pass large expenditures and are designed with a «reserve».

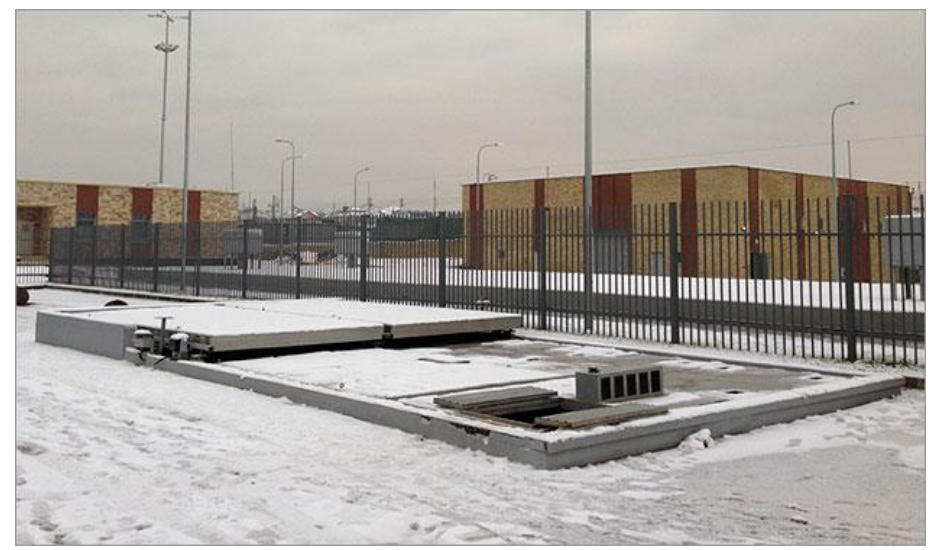

Fig.2. Example of the stationary snow-melting plant. 
In accordance with these considerations, the following zones are proposed:

A. Zone of dense urban development: there are no stationary snow melting units, the collected snow is exported outside the zone

- dense development zone (old buildings);

- dense development zone (new buildings).

B. Industrial building zone, in which stationary snow-melting units can be placed; In this zone, vehicles with snow from Zone A move and vehicles servicing snow removal of the zone itself.

C. Zone of free urban development (the territory of fashionable suburbs with cottages). In this zone, common areas (roads and driveways, areas of children's and sports grounds, etc.) are cleaned with snow-removing equipment and the collected snow is transported either to the nearest landfill for storing snow (this is possible, because snow in this zone is not so as polluted, as in dense urban and industrial buildings), or to the nearest stationary snow melting unit. Territories related to private property are cleaned by the owners with the help of small stationary snow-melting units intended for household plots and working on various types of fuel.

The proposed zone for the placement of stationary snow melting units should, if possible, be outside the residential development zone, since the operation of these facilities can cause inconvenience to residents living in nearby houses. Therefore, for the location of stationary snow melting plants, it is proposed to choose industrial zones and other areas [18-22] remote from residential buildings and having manhole collector hatches. In addition, the hydprophysical properties of the soils should be considered in case of melted snow disposal to the natural relief [23-29].

\section{Results}

In order to determine how many snow melting installations are necessary for each zone, it is necessary to know the amount of snow that is being taken from the territory.

1. For the averaging of the characteristics of the zone, several sections uniformly distributed over the area of the zone was singled out.

2. The location of these sections of the zone in question on the city map should be find, using the regional geographic information system (RGIS).

3. Defining following information for this zone, using the AutoCAD software:

- $\quad$ total area of sites;

- $\quad$ building area on sites;

- the area of green plantations on sites (from the territory of green plantations, snow is usually not exported).

Further calculations are made according to the following dependences.

4. The area is determined from which it is necessary to remove snow, by subtracting from the total area of the plot the building area and the area of green plantations.

$$
S_{\text {clean }-i}=S_{\text {site- } i}-S_{b-i}-S_{\text {green }-i}
$$

where $S_{\text {clean-i }}$ - area, where snow is needed to be clean, $\mathrm{m}^{2} ; S_{\text {site-i }}$ - total area of site, $\mathrm{m}^{2} ; S_{b-i}$ - building area, $\mathrm{m}^{2} ; S_{\text {green-i }}-$ the area of green plantations, $\mathrm{m}^{2}$.

5. In order to determine in the first approximation the amount of snow that must be removed from a given territory, it is necessary to know the maximum amount of snow falling in a day. This value can be found in the regional directory. 
6. Knowing the maximum amount of precipitation, dropping for a day and the area of the site which should be cleaned from snow, the amount of snow in cubic meters $\mathrm{V}_{\text {clean-i, }}$, which must be taken from this site per day, could be determined:

$$
V_{\text {clean }-i}=S_{\text {clean }-i} * h
$$

where $h$ - daily maximum of snow quantity.

7. Knowing the volume of exported snow $\mathrm{V}_{\text {clean-i }}$, it is possible to calculate the layer of exported snow for the whole given section $K_{\text {site-i. }}$

$$
\mathrm{K}_{\text {site-i }}=V_{\text {clean-i}} / S_{\text {site-i }},
$$

where $\mathrm{K}_{\text {site }-i}$ - coefficient, $\mathrm{m}$.

8. Having determined the layer of exported snow for each of the three sites, it is necessary to calculate the arithmetic mean, which will be the layer of exported snow for a given type of territory.

$$
\overline{\mathrm{K}_{\text {slte }}}=\sum_{i=1}^{n} \mathrm{~K}_{i} / n
$$

9. Knowing the layer of exported snow $\overline{\mathrm{K}_{\text {site }}}$ and zone area $S_{z o n e}$, it is possible to calculate the volume of exported snow from the zone $V_{z o n e}$.

$$
V_{\text {zone }}=\overline{\mathrm{K}_{\text {slte }}} * S_{\text {zone }} .
$$

\section{Summary}

In this paper, the issue of clearing the territory of snow with the use of snow melting units was considered. The issues of urban snow-melting process was considered and described. The solution of these issues was proposed. Based on the above developments, the following conclusions can be drawn. The urban area of compulsory export of snow can be divided into three zones by possible to place stationary snow melting units. These zones are divided according to the characteristics listed in the paper. A method for calculating the amount of snow that is mandatory for export is proposed to determine the number of stationary snow melting units serving a characteristic zone. The stated method could be successfully applied under the urban territories development activities.

\section{References}

1. J. Campbell, A. Labelle, A. Langevin, Journal of business logistics, 22, 165-181 (2011).

2. N. Perriera, A. Langevina, J.F. Campbell, European Journal of Operational Research, 189, 508-525 (2008).

3. M. Bittelli, F. Tomei, et.al. Advances in Water Resources, 33, 106-122 (2010).

4. A. Labelle, A. Langevin, J.F. Campbell, Socio-Economic Planning Sciences, 36, 183202 (2002).

5. E. Taulavuori, E.-K. Hellström, K. Taulavuori, K. Laine, Journal of Experimental Botany, 52, 2375 (2001). 
6. B. Chen, T. Jin, X.D. Shi, L.W. Wang, B.L. Nie, Sensors and Transducers, 23, 5964 (2013).

7. A.U. Dolina, A.I. Yarmolinsky, N.V. Barsukova, PROFESSIONAL ENGLISH IN USE, 2016, 31-32 (2016).

8. S.W.S. Millar, Physical Geography, 38, 197-209 (2017).

9. A.V. Lysyannikov, V.G. Shram, N.N. Lysyannikova, Procedia Engineering, 2, 11761181 (2016).

10. O.V. Poliakova, A.T. Lebedev, O. Hänninen, Toxicological and Environmental Chemistry, 75, 181-194 (2000).

11. S. Leroyer, J. Mailhot, S. Bélair, A. Lemonsu, I.B. Strachan, Journal of Applied Meteorology and Climatology, 49, 68-84 (2010).

12. I.V. Galitskaya, N.A. Rumyantseva, Annals of Glaciology, 53, 23-26 (2012).

13. E.E. Nurtdinova, S.V. Nikolaeva, N.G. Kuramshina, E.M. Kuramshin, ECOLOGY OF URBAN AREAS 2014 IV International Conference, 2014, 17-20 (2014).

14. Z. Polkowska, I. Demkowska, K. Cichała-Kamrowska, J. Namieśnik, Ecological Chemistry and Engineering S, 17, 203-231 (2010).

15. S.F. Vinokurov, N.P. Tarasova, A.N. Trunova, V.A. Sychkova, Doklady Earth Sciences, 475, 771-774 (2017).

16. T.M. Muthanna, S.T. Thorolfsson, M. Viklander, G. Blecken, Water Research, 41, 40614072 (2007).

17. K. Liu, M.-J. Tan, Q.-L. Yang, Jiefangjun Ligong Daxue Xuebao, 11, 417-422 (2010).

18. V. Badenko, V. Terleev, A. Topaj, Applied Mechanics and Materials, 635-637, 16881691 (2014).

19. N. Arefiev, V. Badenko, A. Nikonorov, V. Terleev, Yu. Volkova, Procedia Engineering, 117, 20-25 (2015).

20. V.V. Terleev, A.O. Nikonorov, I. Togo, et.al., Magazine of Civil Engineering, 2, 84-92 (2017).

21. R.A. Poluektov, V.V. Terleev, Russian Meteorology and Hydrology, 12, 73-77 (2005).

22. N. Arefiev, V. Terleev, V. Badenko, Procedia Engineering, 117, 39-44 (2015).

23. A. Nikonorov, S. Pavlov, V. Terleev, N. Arefiev, V. Badenko, Yu. Volkova, Procedia Engineering, 117, 258-263 (2015).

24. A. Makarov, A. Mihailova, N. Arefiev, et.al. Procedia Engineering, 117, 225-231 (2015).

25. V.V. Terleev, et.al., Journal International Agrophysics, 24(4), 381-387 (2010).

26. V.V. Terleev, A.G. Topazh, W. Mirschel, Russian Meteorology and Hydrology, 40(4), 278-285 (2015).

27. V.V. Terleev, W. Mirschel, et.al., Eurasian Soil Science, 50(4), 445-455 (2017).

28. N. Arefiev, V. Garmanov, V. Bogdanov, Yu. Ryabov, V. Terleev, V. Badenko, Procedia Engineering, 117, 26-31 (2015).

29. S. Medvedev, A. Topaj, V. Badenko, V. Terleev, IFIP Advances in Information and Communication Technology, 448, 252-261 (2015). 